\title{
Daniel Wagner*
}

\section{CROSS-BORDER RISK MITIGATION IN AFRICA}

\author{
Multilateral institutions have been critical to catalyzing financing and mitigating risk in \\ the developing world. They have been successful in creating new platforms designed to \\ accomplish both objectives, but investors, traders, and lenders continue to perceive high \\ degrees of risk in developing countries. Africa's multilateral institutions have been at the \\ forefront of this effort and are in the process of creating new approaches to risk mitigation, \\ including by pooling their resources.
}

\section{La reducción de riesgos transfronterizos en África}

Las instituciones multilaterales han sido claves para favorecer la financiación y la reducción de riesgos en el mundo en desarrollo. Estas instituciones han sido exitosas a la hora de crear nuevas plataformas concebidas para alcanzar ambos objetivos, aunque los inversores, comerciantes y prestamistas continúan percibiendo altos niveles de riesgo en los países en desarrollo. Las instituciones multilaterales africanas han estado a la vanguardia de estos esfuerzos y se encuentran en el proceso de creación de nuevos enfoques para la reducción de riesgos, incluyendo la puesta en común de sus recursos.

Keywords: African Development Bank, FDI, financial flows, foreign investment, international debt, World Bank.

Palabras clave: Banco Africano de Desarrollo, IDE, flujos financieros, inversión extranjera, deuda internacional, Banco Mundial.

JEL: G20, F10.

\section{Introduction}

Despite the substantial progress that has been made by marshalling resources from the public and private sectors to address perceived risks of doing business in the developing world, investors, traders, and lenders continue to face a plethora of risks. Any one of these risks may prevent them from seriously contemplating proceeding with cross-border investments. Collectively, these risks can pose a nearly insurmountable challenge for large and small businesses and must be

\footnotetext{
* Senior Consultant, Institutional Investment, African Development Bank. Final version: March 2020.

DOI: https://doi.org/10.32796/ice.2020.914.7033
}

tackled if capital is to be mobilized. Another aspect of the challenge is that some potential investors, traders, and lenders have never been to, nor will they ever visit, a given country where a transaction may be located. They may be scared off by "headline" risk or simply decide that engaging in such transactions in developing countries is not worth the headache. There is a vast pool of potential capital residing in developed countries that remains unutilized because of unknown unknowns.

Among the risks regarding which potential investors regularly express concern are political, economic, commercial/payment, foreign exchange, security, corruption, regulatory, environmental, and joint venture/partnership risks. In addition, project/fund size or tenor, country or investor track record, and comparative market returns 
are factored into decisions about whether to proceed with cross-border investments. These risks exist for every type of international transaction, no matter where it may be located, but a lot of investors believe or presume that the risks are worse if they exist in a developing country - whether that is actually true or not. Rule of law, governance issues, and corruption all coalesce to paint a difficult picture for the average investor.

Perceived risks are highest in Africa because there are so many countries on the continent, corruption can be rife, governance levels can be low, and rule of law may be limited. That is why the participation of Multilateral Development Banks (MDBs) and other multilateral institutions are often central to effectively mitigating some of these risks, either on their own or in conjunction with other private or public sector entities. This essay will explore some of the means of addressing cross-border risk, with an emphasis on Africa, and some of the new initiatives that are emanating from the continent, which hold the promise of being replicated elsewhere.

\section{The Role of Multilateral Development Banks}

According to the World Bank, of the cumulative total of USD 163.5 billion in private investment catalyzed by MDB co-financing, the vast majority of that investment (USD 115.5 billion, or $70 \%$ of the total) has gone to projects in Europe, while the developing world has cumulatively received just $30 \%$ of that total (with USD 16.5 billion in private co-financing for projects in Asia, USD 16.3 billion for projects in Latin America and the Caribbean, and USD 14.6 billion for projects in Africa. The Middle East had the lowest absolute amount of private investment mobilization, just USD 0.7 billion or $0.4 \%$ of all private co-financing, as noted in Figure 1 (IFC, 2017). This should be a source of concern for all MDBs, as well as a source of potential motivation to redouble their efforts to catalyze additional private sector investment in infrastructure and other key sectors. The use of risk mitigation instruments is central to that objective.
To illustrate the point, in 2017, just $8 \%$ of infrastructure mobilization was derived from private investment in social infrastructure such as schools and hospitals, reflecting the limited extent of private investment in social sectors in most low - and middle-income countries. Some $92 \%$ of private co-financing was mobilized from investment in economic infrastructure including power, water, transportation, telecoms, and information technology. By contrast, in low - and middle-income countries, $85 \%$ of private capital mobilization was derived from economic infrastructure, with $15 \%$ of the mobilization stemming from social infrastructure (IFC, 2017, p. 14). Europe - not Africa, Asia, Latin America or the Middle East - has been the greatest beneficiary of MDB co-financing.

However, MDBs have a unique set of comparative advantages that make them a natural potential partner for both catalyzing investment and mitigating risk in the developing world. Among these advantages are:

- Market access: MDBs have unrivaled access to their respective marketplaces;

- Vetting and de-risking capabilities: MDB vetting procedures are widely admired and their ability to reduce or remove risk from transactions is in many respects unrivaled;

- Preferred credit status: MDBs continue to get their loans serviced when other entities may suffer repayment interruption in times of sovereign distress; and

- Recovery capabilities: MDBs have superior recovery capabilities by virtue of their preferred credit status, market access, and relationships with host governments.

However, a number of factors have historically prevented MDBs from deploying more capital and mitigating risk in an optimal manner, including:

- Differing motivations for investing in developing countries: MDBs' focus is naturally to promote development while private sector investor focus is primarily to generate returns. Although there is some overlap between the two, the institutional investors wondered whether the disconnect prevented MDBs from becoming more closely aligned with them; 


\section{FIGURE 1}

\section{CUMULATIVE PRIVATE FUND MOBILIZATION UTILIZING CO-FINANCING BY MDBS BY REGION AS OF 2017}

(US\$, billions)

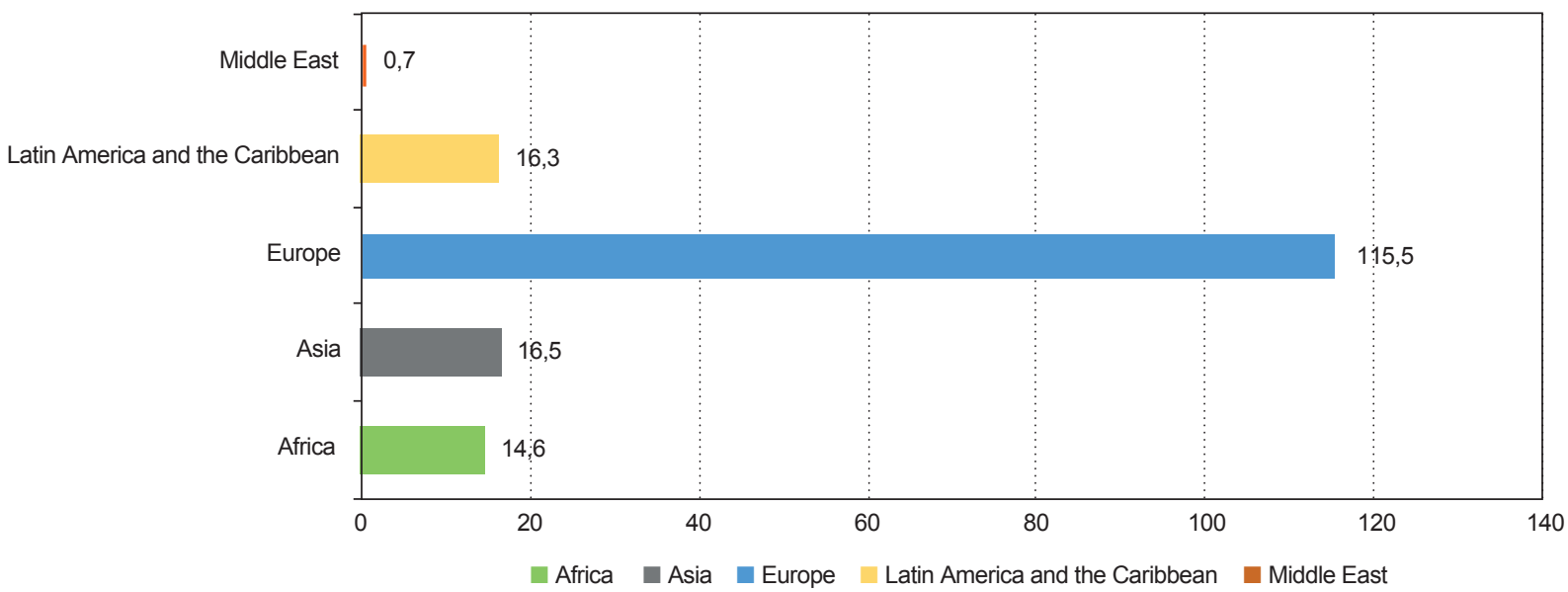

SOURCE: Based on data from the report of the International Finance Corporation (IFC).

- Misalignment in perceptions of risk: Private sector entities often view developing countries - and transactions within them - as being of higher risk than developed countries. By virtue of their preferred creditor status (PCS), AAA-rating, and superior relationships with governments, MDBs are in a better position than private sector entities to assume and manage a plethora of non-commercial risks;

- Willingness to assume more risk: As a result of the above, many investors believe it is justifiable to ask Banks to assume more risk, particularly in the countries that they perceive represent the highest risk. They may also feel (even expect) that it is reasonable to ask MDBs to be willing to take a first-loss position with greater frequency. Few MDBs routinely agree to do so;

- The absence of bankable projects: There are too few projects that warrant financing and many MDBs and private sector investors tend to chase the same projects. This is perhaps the crux of the issue - if there were more bankable projects, there would presumably be less competition between MDBs and private sector investors and more incentive to work with MDBs on projects private investors may not otherwise participate in;

- A lack of coordination within and among MDBs: Some investors view MDBs as lacking coordination, both within departments and between the Banks, when they work together on the same transactions. Enhanced coordination is important to encourage institutional investors to want to work with MDBs on smaller and larger projects;

- Absence of standardization: MDBs can lack standardized procedures, documentation, and investment vehicles. Many investors believe that if there was more standardization, it would be easier to work with them;

- Slow response times/difficult to work with: MDBs can be excessively bureaucratic, slow to respond, and difficult to work with;

- Pricing that is not commercially justifiable: Market pricing of risk tends to be higher than what some MDBs may choose to charge for their loans and guarantees. This creates a mismatch between what MDBs charge for their 
products and what private sector entities seek for assuming the same risk in the same transactions or countries; and

- Lack of knowledge: In spite of the tremendous amount of information MDBs publish about themselves and their operations, their operational processes remain somewhat of a mystery to many investors, who lack general knowledge about MDBs, their underwriting and credit evaluation processes, and how they mitigate their own risk.

Some of these concerns reflect a lack of understanding as regards how MDBs analyze risk, while others are more a function of a misalignment of interests or MDB responsiveness.

\section{Financial and Risk Mitigation Instruments}

MDBs have developed a range of financial and risk mitigation instruments designed to catalyze capital into the developing world while limiting the risks of doing so. Many of these instruments have been in existence for many years, ensuring that the financial community is familiar and comfortable with them, which has helped encourage their broad use. Among the best known and most widely accepted are:

1) Development bonds: Expand the use of longterm, low-cost, fixed-rate, local currency-denominated bonds that are guaranteed by MDBs, enabling domestic pension funds to achieve above market yields on their investments. Host country governments may also guarantee the bonds without actually allocating capital to do so;

2) Local currency guarantees/credit wraps: Local currency guarantees credit-enhance the quality of debt instruments issued to infrastructure projects;

3) Future flow securitizations: wherein the repayment of debt instruments is secured by natural resource (or other) export account receivables to fund infrastructure transactions;

4) Guarantees: Political risk and credit guarantees have been embraced by many MDBs to credit-enhance lenders' and investors' transactional commitments. As guarantees have been more widely utilized, demand for these products continues to grow; and

5) Credit insurance: Credit risk continues to be a primary concern for traders, investors, and lenders, and demand for credit insurance has grown exponentially over the past two decades. Many MDBs include credit insurance among the instruments at their disposal.

That said, there is certainly more that MDBs can do to further catalyze cross-border investment, trade, and lending. In fairness to the Banks, they have been relatively open-minded as regards their willingness to consider creating new tools and platforms, although there is at least some resistance to doing so because of bureaucratic inertia. Nonetheless, competitiveness among the Banks is also serving to help spur an even greater willingness to create new financing and risk mitigation alternatives.

Among the additional innovative options intended to enhance risk mitigation are:

- Unbundling infrastructure projects into components with different risk-return profiles to create component-specific financial products;

- Pooling multiple infrastructure projects with different risk-return profiles into a single portfolio, enhancing diversification;

- Credit enhancement through risk tranching and subordination (including first-loss tranching); and

- Establishing more stand-alone risk mitigation products which focus on risks during the project construction period.

It will of course take some time to translate such ideas into functional products, but such initiatives are currently being discussed and some of them will be launched in the not too distant future.

\section{Catalyzing Investment into Africa}

Africa-based organizations have produced a number of innovative platforms designed to assume greater degrees of risk and catalyze new forms of investment. 
Africa is an ideal destination for such platforms because of the sheer number of countries (54) and the diversity of investment climates. Two of the most prominent platforms have been produced by the AfDB and InfraCredit:

\section{African Development Bank}

The AfDB supported an innovative project to catalyze investments from European pension funds into African agriculture assets. The objective was to: 1 . Structure a means of financial intervention for the benefit of commercial agriculture in Africa, harnessing international capital flows into Africa from Europe by virtue of the Bank's catalytic effect; 2 . Generate a vital demonstration effect on other European and non-African investor classes that may have risk misperceptions with regard to investing in Africa; and 3. Engage large conservative African institutional investors on the viability of this asset class in particular, and of Africa's return potential in general.

The project leveraged the Bank's Partial Credit Guarantee (PCG) to catalyze the deployment of European pension and asset management funds into Africa's agriculture sector, in line with the Bank's Feed Africa strategic priority. This was achieved through the establishment of a Structured Finance Company, which issued agri-linked notes of up to USD 120 million to European Pension Funds. The PCG guaranteed the notional amount of the notes. The proceeds of the notes, together with two other pools of assets worth USD 75 million, were ring-fenced in a Special Purpose Vehicle that invested this pool of capital in a diversified portfolio of Agricultural Farmland Assets and related agricultural infrastructure in Africa Key Objectives.

\section{InfraCredit}

InfraCredit strengthens Nigeria's capital markets by providing local currency guarantees to enhance the credit quality of debt instruments issued to finance creditworthy infrastructure assets in Nigeria. InfraCredit's guarantees act as a catalyst to attract investment from pension funds, insurance companies, and other longterm investors. Doing so addresses constraints of the Nigerian pension market and incentivizes institutional investment in long-term bonds to finance the country's infrastructure assets.

InfraCredit's guarantee is irrevocable and unconditional, guaranteeing payments in accordance with the original payment schedule under a Deed of Guarantee. InfraCredit's guarantee obligations are secured with a right to reimbursement of any amount paid against the Issuer under a Recourse Agreement and further secured with a first fixed charge (legal mortgage) on specific properties and assets of the Issuer and/or a first floating charge over the rest of its assets under a Security Deed. By adopting a zero-loss underwriting policy, InfraCredit only underwrites a portfolio with lower potential default frequency and loss severity characteristics.

\section{Africa Co-Guarantee Platform}

The Africa Co-Guarantee Platform (CGP) is a new platform created to increase the amount of finance available to support trade and infrastructure investment for Africa by enhancing risk mitigation. CGP participants include the AfDB, African Export-Import Bank (Afreximbank), African Trade Insurance Agency (ATI), African Union Development Agency (AUDA-NEPAD), and the Islamic Corporation for the Insurance of Exports and Investment Credit (ICIEC). What makes the CGP unique is that it will serve as Africa's one-stop-shop to provide risk mitigation instruments specifically intended to jointly mobilize resources that would otherwise only be available on a single institutional level.

The platform plans to tackle the most widely recognized impediments to risk mitigation in Africa, such as an absence of investable transactions and the need for greater collaboration to develop innovative risk management solutions for large transactions. Central to the CGP's future success will be timely advisory and project preparation funding to resolve project viability gaps as well as the development of risk solutions that meet 
investor needs. It therefore intends to operate as a results-oriented platform.

The top reasons often cited by private investors for low levels of investment in the developing world include the lack of "bankable" projects, high development and transaction costs, an absence of viable funding models, inadequate risk-adjusted returns, and unfavorable and uncertain regulations and policies (McKinsey Global Institute, 2016). However, given the need for high returns and diversification, institutional investors have reported consistent interest in emerging markets, but very little international institutional investment has been identified for African infrastructure. A core objective of the platform is therefore to reduce or eliminate local currency and foreign risk while funding trade and infrastructure, addressing foreign exchange risk, and creating incentives for good governance.

Some highly innovative schemes for risk mitigation have already been launched, and the CGP will build upon some of the work that has already been done. This includes $100 \%$ credit guarantees, diversified portfolios with first-loss capabilities, and blended finance products (such as a solar power facility via the World Bank Group which is being utilized in Ethiopia, Madagascar, Senegal, and Zambia). Afreximbank has developed specific instruments to cover construction costs for greenfield infrastructure projects. Meanwhile, the Africa Energy Guarantee Facility (AEGF) combined a first loss from Munich Re with a second loss facility provided by the European Investment Bank.

At the present time, traders, investors, and lenders interested in securing cross-border risk management instruments must approach each provider organization individually, making acquisition of coverage a cumbersome and time-consuming process. By providing a single multi-organization platform, the CGP should greatly reduce the time required in an efficient manner. Doing so will also enable dozens of African governments to work in tandem with the platform to provide necessary administrative inputs (such as approvals or counter-guarantees) in a coordinated and efficient manner.
The platform will also provide advisory services that should increase demand for risk mitigation products while growing the pipeline of investable projects. For example, it can invite African governments to provide priority infrastructure projects to experts within the platform to advise on how to structure their projects using risk mitigation instruments. Inherent economies of scale gained from pooling of resources will enable the processing of larger and more numerous transactions while credit-enhancing more projects that might not otherwise be eligible for financing. The ability to engage in fasttrack decision-making will also prove to be a net benefit of utilizing the platform. Use of the CGP will also make transactions more appealing for the private insurance marketplace, which otherwise may not necessarily find certain African transactions appealing. All of the CGP participant organizations are A-rated. Utilizing their role to underwrite transactions will upgrade the ratings of many of the transactions, making them eligible to receive cheaper financing and a broader pool of risk mitigation instruments from a broader array of providers in the private sector. Potential instruments include political risk insurance, credit risk insurance, local currency guarantees, future flow financing, and Sukuk financing.

Potential investors in Africa may not understand the value proposition that such a platform represents, but once they become educated and familiar with it, the CGP will make a unique and valuable contribution to mitigating risk throughout Africa. However, much will depend on the CGP providers working well and efficiently together toward their common objective. Since such institutions are not necessarily accustomed to working closely together, it will undoubtedly take some time before the platform is operating in an optimal manner. The coming months should prove to be important in that regard.

Host governments will also need to do their part to make resources available to the participant providers and investors by creating an enabling environment conducive to cross-border investment. The same is true regarding domestic funding sources - whether 
pension funds, sovereign wealth funds, or commercial organizations - which can determine whether domestic resources are similarly catalyzed. Of course, investors must themselves demonstrate a willingness and capacity to invest.

\section{New AfDB Programs}

\section{Syndication Platform}

To date, MDB capital mobilization efforts have largely focused on catalyzing institutional investors for their non-sovereign loan portfolios. The most commonly used approach is the A/B loan syndication structure, which mobilizes institutional investors behind MDBs in funded risk participations on a project-by-project basis. The International Finance Corporation (IFC), arguably the most experienced $A / B$ lender, recognized the high transaction costs of this piecemeal approach and pioneered the Managed Co-Lending Portfolio Program (MCPP), which sought to achieve greater economies of scale by mobilizing institutional investors in a programmatic manner within pre-agreed limits. One way the IFC attracted significant co-financing interest for the MCPP from insurance companies was by partnering with the Swedish International Development Cooperation Agency to provide a first-loss co-guarantee that enhances risk-adjusted returns for institutional investors. In 2018, through its Room 2 Run initiative, the AfDB pioneered two new non-sovereign balance sheet optimization instruments (portfolio credit insurance and synthetic securitization) to manage its capital and scale up mobilization of institutional investors. The Bank is now in the process of creating a new syndication platform similar to the MCPP. This multifaceted facility will provide investors with a predictable pathway into the African infrastructure sector that automatically includes AfDB participation and options regarding the level of participation by institutional investors. The inaugural transaction, which will occur in 2020, involves securing capital from the nearly $\$ 4$ trillion US municipal securities market - one of the most mature sectors of the capital markets that provides financing for a large portion of US capital investment in American infrastructure.

The sector attracts funding from market funds, insurance companies, endowments, foundations and family office/high net worth investors which have a strong appetite for infrastructure assets that match the tenors of their long-term liabilities. Africa is a natural destination for these investors because it is home to different types of infrastructure assets that need to be developed and financed. In partnership with an investor that has deep reach in the municipal securities market in the US, the Project Development Financing Facility (PDFF) will attract institutional investors to partner with the AfDB, project sponsors, and sovereign and sub-sovereign governments to help develop a more robust infrastructure pipeline of bankable transactions across Africa.

With a USD 1 billion investment, the PDFF is intended to be a permanent source of revolving capital, refinanced through public or private securitizations once the portfolio has reached a critical mass of greenfield or seasoned assets. This refinancing will generate additional capital to continue to finance projects across Africa. The investor will utilize its own balance sheet to ramp and co-finance the AfDB's prioritized projects, based on an agreed set of project characteristics for the portfolio. When a proposed project meets those criteria, the investor will co-invest a minimum dollar amount (or percentage) in the project.

It will have the right to refuse to invest in a given percentage of the Bank's projects presented (i. e. less than $20 \%$ ) over a certain time period (i. e. less than one year). The AfDB will also provide a $70 \%$ unfunded PCG for the portfolio of $B$ loans. In order to commence deploying capital, the AfDB will provide the PCG with a defined notional amount. The PDFF will likely be refinanced well before reaching the USD 1 billion threshold, which will depend on how quickly capital can be deployed into a diverse number of assets. The PCG can expire after the portfolio's cash flows have been securitized. 
One of the advantages of the PDFF is that its inherent risk protections from its subordinated tranches, guarantee, and diversity of tranche amounts allows for flexibility in the number of assets that must be aggregated before a securitization can occur. The portfolio will also include a mezzanine tranche, which may be purchased by insurance companies, pension funds, or other institutional investors, in addition to a first-loss position that the investor will routinely fund. The two tranches will provide $30 \%$ loss coverage before the PCG would be activated.

Among the benefits the PDFF will provide to the AfDB are an expansion of the Bank's reach by creating a captive private sector capital pool, enabling it to be flexible in its capital allocations, and also potentially reducing the Bank's financial and credit exposure to the underlying assets. The facility will enable significant credit risk transfer from the AfDB to the private sector, fund a broad, diversified portfolio of AfDB originated assets, create programmatic, repeatable and scalable transactions with private sector invested capital, reduce the amount of time required to disburse funds following Board approval, and advance the Sustainable Development Goals (SDGs). Investors will benefit from the AfDB's and investor's underwriting expertise and track record, a diversified portfolio of African infrastructure assets, long-term, stable, and consistent cash flows to meet long-term liabilities, and the ability to invest in Environment, Social, Governance and SDG-compliant asset classes.

The PDFF structure is a nimble, commercially viable, scalable, and standardized solution to infrastructure finance that should greatly expand funding of African infrastructure. It is responsive to global demand, disciplined by market viability, and firmly grounded in a successful track record and governance structure that emphasizes accountability, transparency, and verifiable results. The PDFF structure crowds in private sector capital, which should spur new project development across Africa. Since capital markets are the key to moving from billions to trillions, the facility is an elegant solution to affordably financing infrastructure projects, while also generating attractive financial returns.

\section{Islamic Finance Program}

Islamic finance is a financial system that operates according to Islamic law (sharia) and is sharia compliant. As is the case with conventional financial systems, Islamic finance utilizes banks, capital markets, fund managers, investment firms, and insurance companies. Since 2000, a number of regulatory efforts have been created to spur the development of Islamic finance, coinciding with the development of a formal Islamic financial sector.

The use of Sukuk (Islamic finance certificate) issuances for infrastructure development (or to offset budget deficits) is a growing trend in Africa (as demonstrated by recent Sukuk issuances by the Ivory Coast, Morocco, and Senegal). As African sovereigns seek to diversify their funding base, the amount of Sukuk issued is likely to increase. Indeed, Algeria, Egypt, Morocco, and Sudan have already expressed interest in issuing Islamic bonds by 2020, and Moody's expects at least USD 1 billion worth of Sukuk-financed transactions to be executed in Africa by 2020 .

Islamic finance is expected to play a large role in supporting financial inclusion and increasing banking penetration in countries where the rate of the unbanked is high. Moody's estimates that the share of Islamic banking assets (as a percentage of total African banking assets) will rise to more than $10 \%$ over the next five years, from below $5 \%$ as of 2019 . For these reasons, the AfDB plans to introduce an Islamic finance program in 2020.

African countries are seeking to attract Islamic finance capital to support their large infrastructure projects and enhance individual and SME access to financial services. Islamic investors from the Middle East and Asia are also showing more interest in Africa. A significant pool of resources can be harnessed through Islamic finance channels. Therefore, Islamic finance can serve as a potent tool and untapped source to 
help achieve the objectives and strategic priorities of the Bank and its regional member countries.

Given its long-standing expertise in supporting financial and private sector development in Africa, and its strong partnerships with Islamic-oriented financial institutions such as the Islamic Development Bank, the AfDB should be able to play a pivotal role. The Bank will, as appropriate, pursue strategic partnerships with development partners active in the area of Islamic finance in order to proactively and effectively develop and structure interventions that target priority sectors (such as infrastructure, agriculture and energy) and niche groups (such as youth and women). The Bank will also leverage and bundle its various instruments (i. e. partial risk and partial credit guarantees, direct equity, agency lines, syndications, and grant support) in order to achieve these objectives.

\section{Guarantee Programs}

Most MDBs, Development Finance Institutions, and exportcreditagencies have fully-fledged political and credit risk guarantee programs, which are considered to be a standard component of their comprehensive cross-border risk management programs. These programs generally include coverage against a plethora of credit and non-commercial risks which cross-border traders, investors, and lenders encounter on a routine basis - such as expropriation, currency inconvertibility/non-transfer, political violence, and breach of contract risks - as well as sovereign and non-sovereign payment risks.

Part of the reason why these institutions provide such products is because: $i$ ) there is demand for them; ii) the risks addressed often prevent traders, investors, and lenders from pursuing transactions in countries with high degrees of perceived risk; and iii) they are in a unique position to assume such risks by virtue of their AAA ratings, preferred creditor status, and preferential recovery capabilities. The marketplace looks to these institutions to have a catalytic impact by reducing the amount of risk in these transactions.
The AfDB is in the process of enhancing its sweep of such products. It is also engaged in benchmarking and having in-depth discussions with private and public sector entities in the political and credit risk guarantee marketplace. In doing so, it is sending the right signal to the marketplace that the Bank is competitive in this arena and placing itself in a position to more fully service its clientele and member states, while fully meeting its own developmental objectives.

\section{Conclusion}

Multilateral organizations, and in particular MDBs, have a valuable and unique role to play in the catalyzation of finance and mitigation of risk for transactions in the developing world. Indeed, some of their comparative advantages vis-à-vis the private sector are compelling. A number of multilateral organizations are engaged in exciting new approaches to mitigating cross-border risk, particularly in Africa. The good news is that such organizations are often willing to step in when private sector risk mitigation alternatives are unavailable, and they are similarly willing to work with private sector solution providers. The new products and platforms being developed are encouraging and point to an even wider array of risk mitigation options that will be available to international traders, investors, and lenders in the future.

\section{Bibliographic references}

African Development Bank (2018). Unleashing the Potential of institutional investors in Africa, 27-28. AfDB, Cote D'Ivoire.

African Development Bank (2019). Infrastructure Financing: Crowding in Institutional investors. AfDB, Cote D'Ivoire.

IFC (2017). Mobilization of Private Finance by MDBs and Development Finance Institutions, 11-13. International Finance Corporation, United States.

McKinsey Global Institute (2016). Bridging Global Infrastructure Gaps. United States.

Samuels, B. (2019). Business Plan: Africa Co-Guarantee Platform. African Development Bank, Cote D'Ivoire. 
